\section{Finding a patron}

Fortunately for his patients and his peace of mind, Crabbe decided after a few years and much agonising to quit medicine and go to London to venture all as a poet. In 1780, after a difficult interview with his old father, he sailed in a sloop to London, took cheap lodgings in the city, and began to hawk his abundant collection of poems round the booksellers and literary patrons.

For a whole year there were no takers. Crabbe's money ran out as fast as the letters of rejection piled up. In order to eat he had to sell clothes, books, and a case of his redundant surgical instruments. Even so, the day came when "absolute want stared him in the face ... the best he could hope for was, dismissing all his dreams of literary distinction, to find the means of daily bread in the capacity of a druggist's assistant." Characteristically, he tried one last fling for freedom. He sent a letter to the statesman Edmund Burke, from one "without a friend, without employment, without bread," enclosing an assortment of his poems and imploring the great man to see him. The happy outcome is best told in the words of Crabbe's son's biography:

Mr Burke ... immediately appointed an hour for my father to call upon him at his house in London; and the short interview that ensued entirely, and for ever, changed the nature of his worldly fortunes . . He went into Mr Burke's room a poor young adventurer, spurned by the opulent, and rejected by the publishers, his last shilling gone, and all but his last hope with it; he came out virtually secure of all the good fortune that, by successive steps, afterwards fell to his lot.

After his short talk with the starving poet Burke wrote to his friend Joshua Reynolds, "He has the mind and manners of a gentleman." Crabbe was immediately asked to stay at Burke's country home in Beaconsfield, where he was treated as one of the family, provided with rooms and books, and introduced to Charles
James Fox and Reynolds, who later invited Crabbe to meet Dr Johnson. The literary networks had begun to operate.

\section{Poet and churchman}

Burke continued to treat Crabbe as a favourite son. With the great man as his friend and adviser, Crabbe rapidly got into print. He also got into the church, that useful refuge for writers in need of a secure income and light duties. His first appointment was to a curacy at Aldeburgh, and after many moves round England he spent his final years as rector of Trowbridge in Wiltshire, far from the harsh landscape of his youth. The year after his death in 1832 a monument was erected over his grave in the chancel of the parish church, with an inscription including the words:

Born in humble life, he made himself what he was. By the force of his genius, he broke through the obscurity of his birth yet never ceased to feel for the less fortunate.

Literary genius would certainly not be claimed for Crabbe today. He lacked the true poet's ear, and even his most fervent admirers have to admit that his jogtrot couplets often degenerate into mere doggerel. But if he is far from being a great poet, he is certainly a brilliant craftsman on the narrow canvas that he chose and above all a passionate humanitarian. His best testimonial is that of John Simon, the pioneer health reformer, who praised Crabbe, Cowper, and Burns for their poetic gift of awakening "tens of thousands who had never troubled themselves to read argumentative works of divinity or politics to new sympathies with their fellow men."

The painting on the front cover, by Anne Bruce, is of Blythburgh Hospital, formerly a workhouse in the part of Suffolk where George Crabbe worked.

\title{
The fortification spectra of migraine
}

\author{
GORDON T PLANT
}

When I was a medical student on holiday in Holland I visited the town of Naarden, an aerial view of which is shown in figure 1 . A single glance at the photograph of these remarkable fortifications made me realise why one of the most common varieties of visual aura in migraine is referred to as the "fortification spectrum."

Although a number of authors have correctly stated the origin of the expression, ${ }^{1-3}$ I have found considerable confusion among medical students and practising physicians about its meaning. When asked, most will suggest that the term refers either to the castellated or crenellated appearance of battlements or, less convincingly, to the intense ("fortified") visual sensation. Even more confusion surrounds the term "teichopsia," which has the same meaning as fortification spectrum but is usually taken to mean "flashing lights."

There are a few instances where the general misunderstanding has resulted in published errors. For example Duke-Elder states: "The usual visual disturbances, however, are very striking, consisting of the appearance of brightly coloured, shimmering spectral lights (TEICHOPSIA)." ${ }_{4}$ The definition of teichopsia in the Oxford

Physiological Laboratory, Cambridge CB2 3EG, and Addenbrooke's Hospital, Cambridge CB2 2QQ

GORDON T PLANT, MB, MRCP, research associate and honorary registrar
English Dictionary (1971) as "Temporary blindness sometimes accompanying ophthalmic headache" is, I think, off the point and sufficiently vague as to be misleading.

Sacks states that fortification spectra are so called because of their similarity to the ramparts of a walled city. ${ }^{5}$ Sacks also repeats Singer's suggestion that certain illustrations of the visions of the nun and mystic Hildegard of Bingen (1098-1180) may have had a migrainous basis. ${ }^{\circ}$ Both authors show, as evidence for this assertion, the occurrence of "typically migrainous fortification figures" in some of the illustrations. These are of the form $几 \backsim 几$, which in my experience is never reported in migraine.

My interest in this topic has grown into a crusade since a colleague (a visual physiologist) recently described to me his first attacks of classical migraine. He was particularly interested that his aura had consisted of zig zags and not fortification spectra.

\section{Origin of the term}

I was aware that most authorities quote Hubert Airy's paper of 1870 as the origin of the term. ${ }^{7}$ A little further research showed that the term had been used independently by no fewer than three distinguished people.

The earliest was Dr John Fothergill (1712-80), the eighteenth century London physician who formed a Society of Physicians and published its proceedings at his own expense. He was responsible 
for the earliest English language description of trigeminal neuralgia as well as of migraine. He read a paper on migraine before the Select Society of Licentiates on 14 December 1778, which was published four years after his death in 1784 in the last volume of his publication Medical Observations and Inquiries. ${ }^{8} \mathrm{He}$ admits to "having had some little experience of this complaint," and was probably describing his own experience when he wrote (p 120):

From many incontestible proofs, that butter in considerable quantities is injurious, it is less used in many families. It is found, by many to be very difficult of digestion, especially when toasted before the fire, or fried, as well as in sauces. Many people, apparently robust, and whose organs of digestion are strong, often find themselves much disordered by large quantities of butter. Nothing more speedily and effectually gives the sick head-ach, and sometimes within a few hours. After breakfast, if much toast and butter has been used, it begins with a singular glimmering in the sight; objects swiftly changing their apparent position, surrounded with luminous angles, like those of a fortification. Giddiness comes on, head-ach and sickness. within our own organisation distinct from that of our own personality."

Brewster (1781-1868)—physicist, migraineur, and inventor of the kaleidoscope-also tackled the problem of the anatomical structure in which his aura originated. ${ }^{12} \mathrm{He}$ considered the disorder to be retinal because the irregular outline reminded him of the appearance of the retinal blood vessels: "The parts which are in these cases affected extended irregularly from the foramen centrale to the margin of the retina, as if they were related to the distribution of blood vessels." This explanation contains a very straightforward error: Brewster was clearly aware from the remainder of his description that the disorder was binocular but ignored the fact that the pattern of retinal blood vessels does not correspond in homonymous fields. Brewster's conclusions were of more than passing interest. In 1824 another fellow of the Royal Society, Wollaston, had described his own attacks of transient hemianopia and concluded from his observations that there must be a partial

This paper was also published in the same year in Fothergill's collected works. ${ }^{9}$ The passage quoted does not appear in this other version, and it may well be relevant that the editor, J C Lettsom, comments that some pages were missing from the manuscript. The passage above highlights Fothergill's opinion expressed in the same article (p 106) that: "the head-ach proceeds from the stomach; not the reverse, as has been the opinion of many who are sufferers by it." 8

The next published use of the description appeared in an article by the astronomer Sir J F W Herschel (1792-1871), writing again from his own experience. He delivered a lecture entitled "On sensorial vision" before the Philosophical and Literary Society of Leeds on 30 September 1858 and published it in $1866 .^{10} \mathrm{He}$ was clearly unaware at the time that the disorder was a manifestation of migraine perhaps because he himself had no headache after the attack. In the lecture he describes a variety of

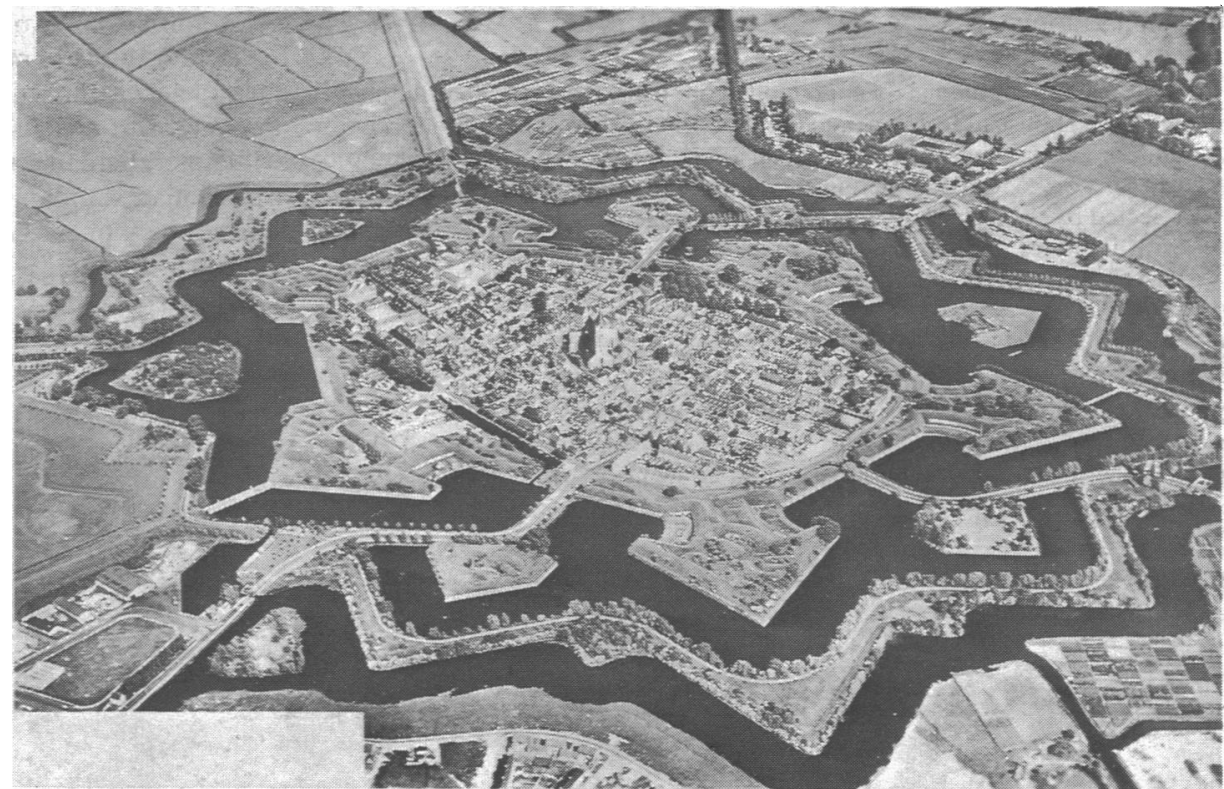

FIG 1-Aerial view of Naarden. visual phenomena such as after images (which he calls ocular spectra) and other instances where he had observed regular geometric patterns-for example, under the influence of chloroform-and discusses how they might be produced. He argues that although ( $p$ 406):

...we all know how easy it is to imagine faces in casual blots, or to see pictures in the fire ... no such explanation applies to the class of phenomena now in question, which consist in the involuntary production of visual impressions, into which geometrical regularity of form enters as the leading character, and that under circumstances which altogether preclude any explanation drawn from a possible regularity of structure in the retina or optic nerve.

I was sitting one morning very quietly at my breakfast table doing nothing, and thinking of nothing, when I was startled by a singular shadowy appearance at the outside corner of the field of vision of the left eye. It gradually advanced into the field of view, and then appeared to be a pattern in straight-lined-angular forms, very much in general aspect like the drawing of a fortification, with salient and re-entering angles, bastions, and ravelins with some suspicion of faint lines of colour between the dark lines. The impression was very strong: equally so with the eyes open or closed, and it appeared to advance slowly from out of the corner till it spread all over the visual area, and passed across to the right side, where it disappeared. I cannot say how long it lasted, but it must have been a minute or two.

He concluded that the regular structure was imposed on these phenomena by the mind but unconsciously. We now know that there is a regularity of structure in the visual cortex,${ }^{11}$ which partly explains the remarkable appearance of fortification spectra. ${ }^{11}$ Herschel, however, was compelled to conclude that these phenomena provided "evidence of a thought, an intelligence, working

decussation of the optic nerves. ${ }^{13}$ Wollaston describes both a left and a right hemianopia occurring 20 years apart and each lasting about 20 minutes. The first was induced by exercise, the second had no precipitating cause. It seems most likely that these attacks were migraine. An uncanny twist to the story is that he also describes a friend who acquired a permanent hemianopia, and it is known that Wollaston himself at necropsy was found to have a tumour affecting the lateral geniculate body, indicating that in his last illness Wollaston also acquired a permanent hemianopia.

Be that as it may, there was no anatomical evidence at the time for the partial decussation which Wollaston so brilliantly deduced from his own experiences; Brewster did not believe in the idea and published his own experiences of visual migraine in order to refute Wollaston's claim.

\section{Airy's description}

Although he knew Herschel's account by the time he published his own (1870), Dr Hubert Airy refers to an entry in his journal of 6 October 1854, in which as a schoolboy he recorded impressions of his first attack:

When it was at its height it seemed like a fortified town with bastions all round it, these bastions being coloured most gorgeously. ... All the interior of the fortification, so as to speak was boiling and rolling about in a most wonderful manner as if it was some thick liquid all alive. ${ }^{\text {? }}$ 
Airy was the first to point out that some accounts of "hemiopsia" (such as Wollaston's ${ }^{13}$ ) referred to a different form of the disorder (homonymous field defects without fortification) and he proposed:

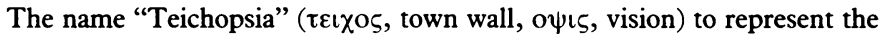
bastioned form of transient hemiopsia which I have been describing, not without a reminiscence of some words of Tennyson's:

$$
\begin{aligned}
& \text { "as yonder walls } \\
& \text { Rose slowly to a music slowly breathed, } \\
& \text { A cloud that gathered shape." }
\end{aligned}
$$

Hubert Airy's paper was undoubtedly one of the most influential publications on migraine of all time. ${ }^{7}$ His account of his own migrainous aura was beautifully illustrated, and the illustrations were reproduced by both Liveing ${ }^{14}$ and Latham ${ }^{15}$ in their contemporary monographs and by Gowers (fig 2) to accompany his Bowman lecture to the Ophthalmological Society "Subjective visual sensations." The latter was published both in the Transactions ${ }^{16}$ and

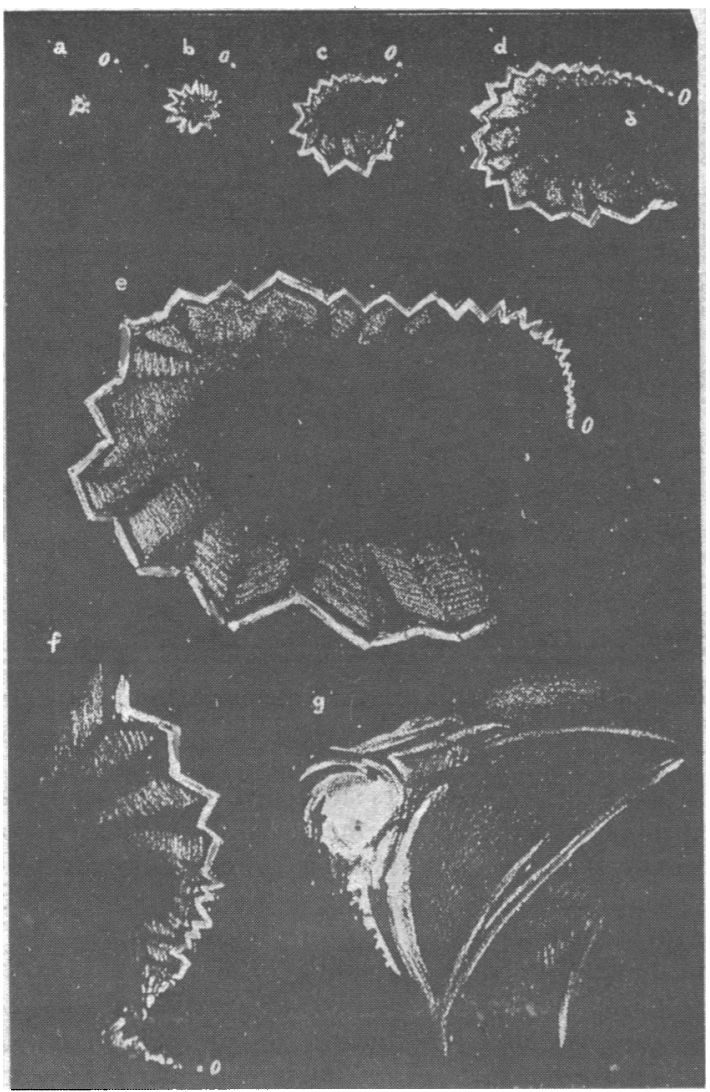

FIG 2-One of Airy's illustrations of his migrainous aura used by Gowers to illustrate his lecture "Subjective visual sensations." 16

later in a collection of lectures. ${ }^{17}$ These three authors, particularly Gowers, were likely to have helped in popularising the term coined by Airy.

Liveing mentions ( $p$ 83) that Dr Airy described the characteristic "bastioned" outline and that without any knowledge of Dr Fothergill's account of the malady made use of the same illustration of a fortification. ${ }^{14}$ Liveing makes it clear that he attended when Airy's paper was given to the Royal Society in February 1870, and we can presume that he subsequently informed Airy of Fothergill's writings on the subject because when Airy came to publish the paper in 1870 he stated that: "very lately ( 7 April, 1870)" he had been shown Fothergill's description." $\mathrm{He}$ does not, however, give Liveing the credit for pointing out the precedent. Liveing's monograph was not published until 1873.

Gowers's use of the term fortification spectra would certainly have been influential. In the initial published version of "Subjective visual sensations"16 he states (p 23) that: "Its projecting and reentrant angles bear a resemblance to the plan which the French engineer Vauban first devised as the most effective for the defence of a fortress." "It In the later version, however, he had altered this to (p 23) "The result bears some resemblance to the place of a fortification and hence it is sometimes called the 'fortification spectrum.' "17 Could this vague explanation have been the more widely read and therefore partly responsible for the subsequent confusion?

\section{Other descriptions}

Other celebrated migraineurs described their attacks in the nineteenth century, but the terms used did not become as popular as Airy's fortification spectra. Caleb Hillier Parry (1755-1822), for example, described the aura as follows in his widely read Elements of Pathology and Therapeutics (p 357): "after a short time a corruscation of light in a zig-zag form plays rapidly backwards and forwards at one corner."

He describes the attack in more detail in Local Affections of the Nervous System Affections of Sight-Darkness before the Eyes, published posthumously ( $\mathrm{p} 557$ ):

The general sight did not appear affected; but when I looked at any particular object, it seemed as if something brown, and more or less opake, was interposed between my eyes and it.... After it had continued a few minutes, the upper or the lower edge, I think always the upper, appeared bounded by an edging of light of a zig-zag shape, and corruscating nearly at right angles to its length. ${ }^{19}$

In this account he also makes it clear that he is describing his own attack. In both of these accounts it is apparent that Parry did not appreciate (as Fothergill certainly did) that this disorder was related to migraine. Indeed, in Elements of Pathology and Therapeutics he gives the description as an "exemplification of a salutary process." He believed that the "luminous corruscations" were (like muscular exercise, fits, and rigors) "salutary processes," the function of which was to "restore the balance of the circulation." Hence: "If no such corruscation occurs, or if it very speedily ceases, severe affections of the head, as pain, confusion, vertigo, a forgetfulness of proper words, etc, together with a painful sense of stricture in the stomach, or colon, succeed." Clearly he was aware of many migrainous phenomena, including dysphasia, but had not related these to his clinical experience of sick headaches or hemicrania.

In France, Piorry, who was widely read, also used the term zig zags: "Bientôt, et après une ou deux minutes, se dessine à l'entour de l'espace obscurci un arc de cercle lumineux, colouré chez quelques individus, mais pâle chez d'autres, disposé en zig-zags." 20

The same expression was employed by Professor Du Four in a letter quoted by Hubert Airy: "Les lignes avec zig-zags se produisent alors bientôt; mais, dans les premières minutes, les zigzags me semblent plus petits."

Both Piorry and Du Four were describing their own attacks. The latter wrote the letter quoted above to Hubert Airy's father, the astronomer royal Sir George Airy, who had published an account of his own migraine in 1865: "The arch is small at first, and gradually increases in dimensions. The zig-zags nearly resemble those in the ornaments of a Norman arch, but are somewhat sharper." ${ }^{21} \mathrm{He}$ also described the appearance as "serrated." The complete account was later translated in Les Mondes (16 April 1868) and prompted Du Four's correspondence on the subject.

\section{Nineteenth century knowledge of fortification}

I think we can assume that because "fortification spectra" was subsequently adopted rather than the other terms (corruscations, zig zags, serrations, dog tooth moulding) it must have been found to be particularly apt by nineteenth century physicians. If this is the case then we would expect bastioned fortifications such as Naarden to have been very familiar in the nineteenth century.

Fortifications of this type were first developed in early sixteenth century Italy, on which Charles VIII of France had descended in 
1494 with the first fully mobile siege guns. Among other developments mediaeval circular towers were transformed into bastionspentagonal projections having their bases on the line of the main works-to eliminate the "dead ground" in front of each circular tower where the attacker might approach out of any line of fire. ${ }^{22}$ The ravelin (also mentioned by Herschel) was a freestanding triangular work situated in front of the bastions to provide a forward defence. Vauban (1633-1707), in the employ of Louis XIV, the Sun King, later established the building of such defensive works (and their attack) as an engineering and military science. He did not, however, invent them as Gowers stated.

Of present relevance is the fact that such fortifications changed little until the invention of rifled artillery, which was as late as 1860 (see Duffy ${ }^{22}$. There were few such defensive works in Britain (although Berwick on Tweed and Fort George in Inverness provide two surviving examples), but many hundreds of European towns, cities, and fortresses had this appearance in ground plan well into the latter half of the nineteenth century. Clearly the opportunities for urban expansion were limited, and few examples survive that are as beautifully complete as Naarden. Though to us the word fortification first conjures an image of a mediaeval castle, it is not surprising that in the nineteenth century it was Vauban's elaborate geometric structures that were more readily suggested.

\section{Spectra and chevaux de frise}

Teichopsia is not the only widely misunderstood term. "Spectrum" is often taken to imply the appearance of colours in the aura. For example, in Osler's A System of Medicine (p 757): "For most the scotoma is in constant motion, flashing in its spectral zig-

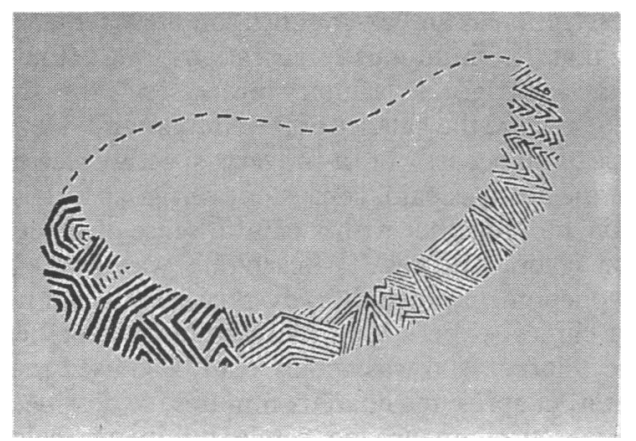

FIG 3-Aura of the watercolour artist, $\mathrm{Mr} \mathrm{B}$-, which Gowers described as chevaux de frise. ${ }^{16}$

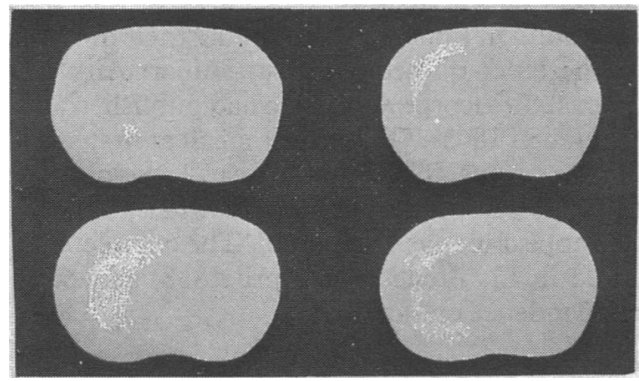

FIG 4-Aura of Dr K S Lashley. ${ }^{1}$

zag fashion, thus causing the classical name "fortification spectrum" from the play of colours. ..."23 Airy made it quite clear that colours may or may not be observed in fortification spectra, and Gowers discusses the use of the term spectrum in the sense of an apparition. ${ }^{17}$
Neither does teichopsia constitute the only example of a military visual reference being used to describe a migrainous phenomenon. As well as Airy's drawings, Gowers also illustrated his Bowman lecture with the work of a contemporary "distinguished water

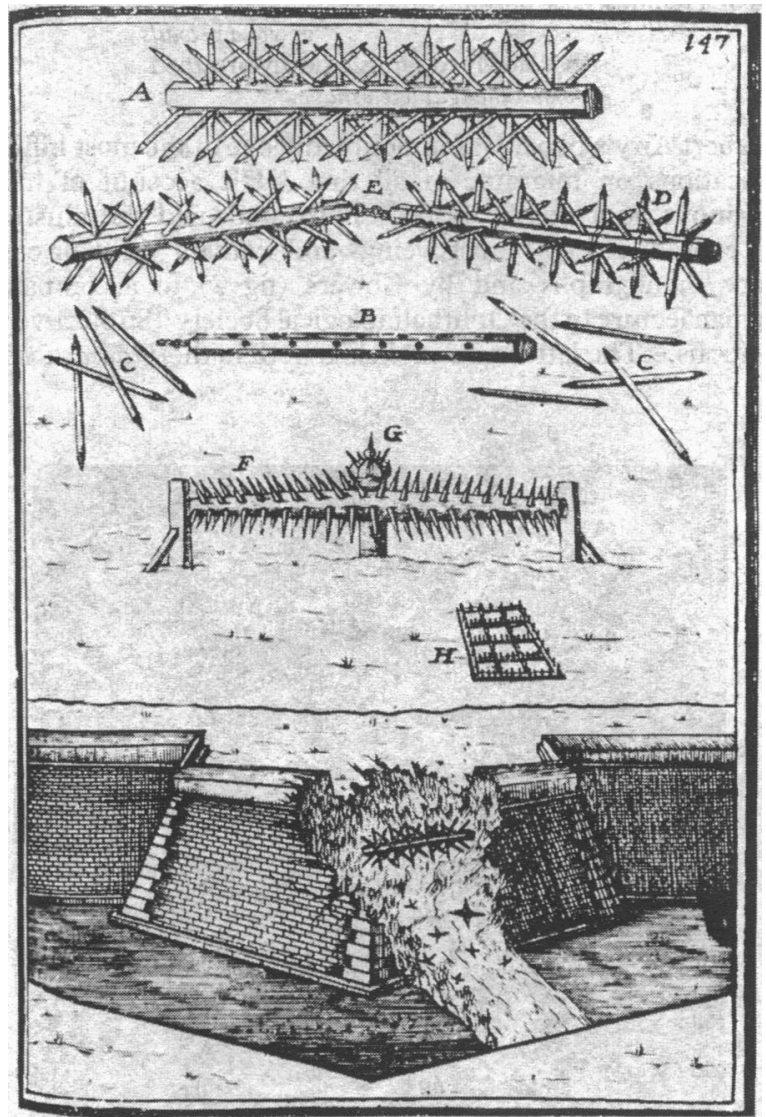

FIG 5-Details of the construction of a chevaux de frise from Mallet. ${ }^{24}$

colour artist, Mr B-."' Gowers suggested that the particular aura experienced and depicted by the artist, in which a complex interlacement of lines occurs, resembled a "chevaux de frise" (fig 3 ). Lashley, neurophysiologist and one of the best known twentieth century migraineurs, experienced a very similar aura (fig 4), ${ }^{1}$ and Sacks misquotes Gowers by describing Lashley's aura as a "cheveux de frise" (p 79). ${ }^{\text {s }}$

In fact, a cheval de frise (chevaux de frise being the collective singular) was a device made of a beam, hexagonal in cross section, to which were attached radially wooden stakes (fig 5). ${ }^{24}$ It resembled a giant hair curler and was placed across a breach in the defensive wall to hinder attackers. A metal rail with radiating spikes running along the top of walls or railings was also referred to as a chevaux de frise. The term was used by Dickens ${ }^{25}$ when Mr Pickwick on his visit to the Fleet Prison noted that the racket ground was surrounded by a high brick wall with iron "chevaux-de-frise" at the top and is likely to have been familiar to the Victorians. Duffy suggests that cheval de frise should be translated as frizzy horse (p 69), ${ }^{22}$ but in fact it was adopted from the Dutch (first attested in French in 1572) and derives from the Friesian Islands, where the weapon was invented. The term has no connection with frizzy hair.

I thank the Wellcome Trust of Great Britain for its support and also Professor W I McDonald, who encouraged me to put down on paper the fruits of idle curiosity, and Professor R A Leigh for his helpful advice.

\section{References}

1 Lashley KS. Patterns of cerebral integration indicated by the scotomas of migraine. Archives of Neurology and Psychiatry 1941:46:331-9.

2 Richards W. The fortification illusions of migraine. Sci Am 1971;224:88-96. 
3 Glaser JS. Neuro-ophthalmology. Maryland, United States of America: Harper and Row, 1978:300. 4 Duke-Elder. Text-book of ophthalmology. Vol 4. 1st ed. London: Henry Kimpton, 1949:3684. 5 Sacks OW. Migraine, the evolution of a common disorder. Los Angeles: University of California Press, 1970

6 Singer C. From magic to science. London: Ernest Behn, 1928:230-4

7 Airy H. On a distinct form of transient hemiopsia. Philos Trans $R$ Soc Lond 1870;160:247-70.

8 Fothergill J. Remarks on that complaint, commonly known under the name of the sick head-ach. Medical observations and inquiries by a sociery of physicians in London. Vol 6. 1st ed. London: Medical observations and in

9 Fothergill J. The works of John Fothergill, MD. Vol 3. (Lettson JC, ed.) London: Charles Dilly, 1784:219-56.

10 Herschel JFW. Familiar lectures on scientific subjects. London: Alexander Strahan, 1866:406

11 Hubel DH, Wiesel TN. Functional architecture of macaque monkey visual cortex. Proc $R$ So Lond [Biol] 1977;198:1-59.

12 Brewster D. On hemiopsy, or half-vision. Philosophical Magazine 1865;29:503-7.

13 Wollaston WH. On semi-decussation of the optic nerves. Philos Trans $R$ Soc Lond 1824;114: $222-31$

14 Liveing E. On megrim and sick headache. London: Churchill, 1873.
15 Latham PW. On nervous or sick-headache, its varieties and treatment. Two lectures. Cambridge: Cambridge University Press, 1873.

16 Gowers W. Subjective visual sensations. Trans Ophthalmol Soc UK 1895;15:20-44.

17 Gowers W. Subjective sensations of sight and sound, abiotrophy and other lectures. London: Churchill, 1907:18-41.

18 Parry CH. Elements of pathology and therapeutics. Vol 1. 2nd ed. Bath: Richard Cruttwell, 1825:357.

19 Parry $\mathrm{CH}$, ed. Collections from the unpublished medical writings of the late Caleb Hillier Parny. London: Underwoods, 1825:557.

20 Piorry PA. Du procède operatoire à suivre dans l'exploration des organes par la percussion. Mediate, e collections de memoires sur la physiologie, la pathologie et la diagnostic. Paris: Baillière, 1831:409. 21 Airy GB. The astronomer royal on hemiopsy. Philosophical Magazine 1865;30:19-21.

22 Duffy C. Fire and stone: fortress warfare. Vancouver: Douglas David \& Charles, 1975:9-18.

23 Smith EJ. The migraines. In: Osler W, Macrae T, eds. A system of medicine. Vol 8. London Hodder and Stoughton, 1910:750-68.

24 Mallet A. Les travaux de mars. Vol III. Paris: Frederic Leonard, 1672:147.

25 Dickens C. The Pickwick papers. Ch 41. London: Chapman and Hall, 1837.

(Accepted 2 December 1985)

\section{The 100th birthday of appendicitis}

\section{HAROLD ELLIS}

This year is the centenary of the birth of one of the words most frequently used in medicine by both practitioners and the general public-appendicitis. At the meeting of the Association of American Physicians held in Washington in June 1886 Reginald $H$ Fitz presented a paper on "Perforating inflammation of the vermiform appendix; with special reference to its early diagnosis and treatment," in which he stated": "As a circumscribed peritonitis is simply one event, although usually the most important, in the history of inflammation of the appendix, it seems preferable to use the term appendicitis to express the primary condition."

Lorenz Heister, professor of surgery in Altdorf, Franconia, gave the first undoubted account of appendicitis in November 1711. In dissecting the body of a malefactor he found "the vermiform process of the caecum preternaturally black, adhering closer to the peritoneum than usual. As I now was about to separate it, by gently pulling it asunder, the membranes of this process broke ... and discharged two or three spoonfuls of matter. This instance may stand as proof of the possibility of inflammations arising, and abscesses forming, in the appendicular, as well as in other parts of the body which I have not observed to be much noticed by other writers."

Claudius Amyand, surgeon first at Westminster and then at St George's hospitals, was the first to report removal of at least part of the appendix. This case was reported at the Royal Society in 1736: the patient, a boy of 11, had a right scrotal hernia associated with a discharging sinus. This was explored and found to contain the appendix perforated by a pin. Amyand reported": "It was the opinion of the physicians and surgeons present to amputate this gut; to which end a circular ligature was made about the sound part of it 2 inches above the aperture, and this being cut off an inch below the ligature was replaced within the abdomen." Recovery followed.

\section{Typhlitis and perityphlitis}

Occasional reports of the necropsy findings of perforated gangrenous appendixes followed, and there seemed little doubt that gradually the pathological features of this condition would become well documented. In 1830, however, Goldbeck of Heidelberg published a graduation thesis in which he coined the

Surgical Unit, Westminster Hospital, London SW1P 2AP

HAROLD ELLIS, DM, MCH, professor and head of department

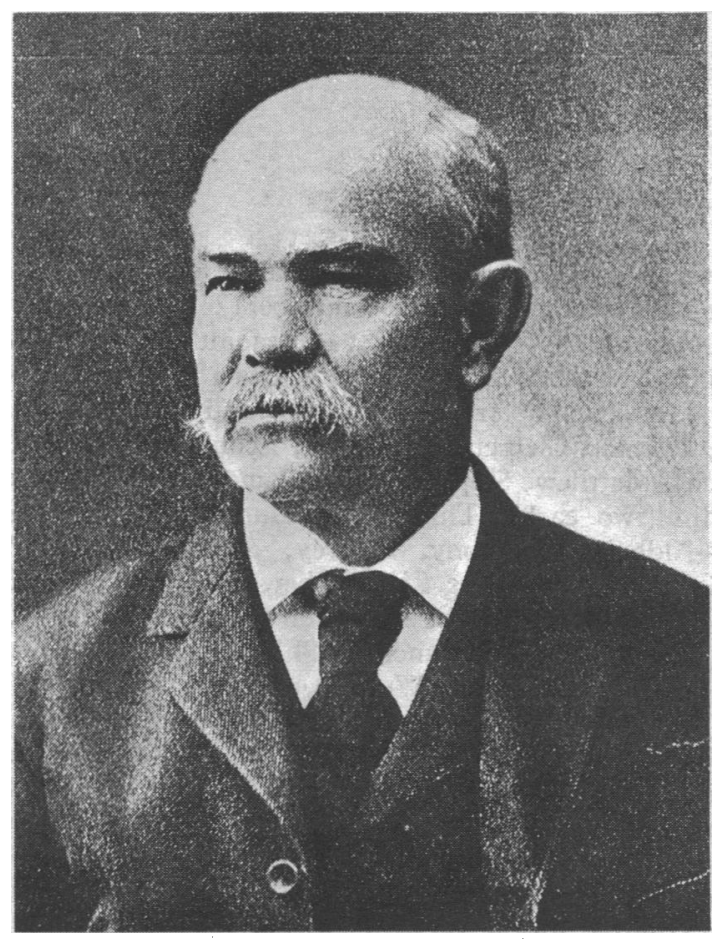

Reginald Heber Fitz. (From Harvard Medical Alumni Bulletin (1983) by permission of the editor.)

term "perityphlitis." Without any good evidence he concluded that irritation of the mucosa of the caecum caused inflammation of the overlying cellular tissue. This thesis was strongly championed by the great Baron Dupuytren in his "Lectures on Clinical Surgery," published in 1839, so that the terms typhlitis and perityphlitis remained in use until the end of the nineteenth century. ${ }^{2}$ This was despite the fact that other more discerning observers, including Thomas Hodgkin, Richard Bright, and Thomas Addison, were correctly ascribing the clinical and pathological features of inflammation of the right iliac fossa to the appendix.

There is no doubt, however, that it was the contibution of Reginald Fitz, based on a review of 257 cases of "perforating inflammation of the appendix," that showed quite clearly that abscesses in the right iliac fossa were in the main due to appendicitis 